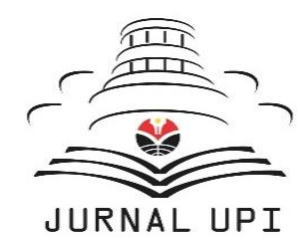

INDONESIAN JOURNAL OF APPLIED LINGUISTICS

Vol. 10 No. 2, September 2020, pp. 538-550

Available online at:

https://ejournal.upi.edu/index.php/IJAL/article/view/28605

https://doi.org/10.17509/ijal.v10i2.28605

\title{
Reaching out to the readers: The translation of Japanese manga in Malaysia
}

\author{
Yean Fun Chow", Haslina Haroon, and Hasuria Che Omar \\ School of Humanities, Universiti Sains Malaysia, 11800 Minden, Pulau Pinang, Malaysia
}

\begin{abstract}
One of the most recognisable aspects of Japanese pop culture which has invaded Malaysia is the Japanese comic or manga. It appears in translation in both Malay and English in Malaysia. Taking into account its foreign origin and the fact that translated manga is targeted at a local readership, translators often resort to the use of notes in the translations in order to assist the readers. This study, thus, intends to examine the type of notes used in the Malay and English translations of Japanese manga, and to determine items in the Japanese manga which required clarification and for which notes are provided. To analyse the use of notes by the translator in the translated manga, this study adopts a qualitative content analysis approach. The analysis involves six Japanese manga and their corresponding translations in Malay and English. The findings show that the translators employ the use of three different types of notes in the translation: notes on the image, notes in the gutter and notes at the end of the text. The analysis also shows that the elements in the Japanese manga which require clarification in translation are giongo/gitaigo, inscriptions, culture-specific elements, wordplay, technical terms and honorifics. There is also a minor difference between the Malay and English translations where the use of notes is concerned. Based on the findings, it is concluded that notes are important in translated versions of the manga in Malaysia in that they provide assistance to readers in understanding certain aspects of the manga.

Keywords: Comics; manga; notes; paratext; translation

\begin{tabular}{ccc} 
First Received: & Revised: & Accepted: \\
5 April 2020 & 4 July 2020 & 6 August 2020 \\
Final Proof Received: & & Published: \\
26 September 2020 & & 30 September 2020 \\
\hline
\end{tabular}

\section{How to cite (in APA style):}

Chow, Y. F., Haroon, H., \& Omar, H. C. (2020). Reaching out to the readers: The translation of Japanese manga in Malaysia. Indonesian Journal of Applied Linguistics, 10(2), 538-550. https://doi.org/10.17509/ijal.v10i2.28605
\end{abstract}

\section{INTRODUCTION}

The international trade of manga copyright brings substantial income to Japan, contributing to approximately $73 \%$ of Japan's domestic revenue (Japan Book Publishers Association, 2017). Today, the Japanese manga is available not only in Japanese but also in many different languages to cater to worldwide interest. This interest is, to some extent, reflected in the various studies carried out focusing on various aspects of the translation of Japanese manga into various languages, for instance, into German (Jüngst, 2004), English (Brienza, 2009; Takeyama \& Armour, 2015), English and Spanish (Inose, 2010), English and
German (Fujimura, 2012), Chinese (Ding, 2014), Turkish (Okyayuz, 2017), and Indonesian (Ningsih et al., 2018).

In Malaysia, manga appears in two forms: (1) the original manga which is imported from Japan, and (2) the translated version in local languages (Mamat et al., 2015). The translated manga is distributed by Kadokawa Gempak Starz Sdn. Bhd. (Kadokawa Corporation, 2015). The Japanese comic has also attracted a huge following in Malaysia, which in turn has led to a number of research focusing on manga in the context of Malaysia. For instance, the study by Mamat et al. (2019) compared the development of Japanese comics and animation

\footnotetext{
* Corresponding Author

Email: chowyf21@gmail.com
} 
with the development of comics and animation in Malay, while the study by Mamat et al. (2015) looked into the similarities and differences between the Japanese manga and dojinshi, a form of amateur or professional manga publications in Malay which are made by fans. Other studies investigated the use of Japanese manga and anime in Japanese education at Malaysian public universities (Mamat et al., 2018) and examined the plot in selected shojo manga (Mamat et al., 2016).

There is, however, a surprising paucity of research focusing on the translation aspect of manga in Malaysia. The studies which have been carried out so far investigated the translation of elements of humour in manga (Mohd. Hanif, 2014) and the translation of Japanese onomatopoeia in manga in the forms of giongo and gitaigo (Chow \& Che Omar, 2019). This study, therefore, is an attempt at addressing this paucity of research in the area of manga translation in Malaysia and hopes to contribute to the discourse on the translation of the Japanese comic in Malaysia.

Considering that translated manga is targeted at the local readership, and that the purpose of a translation is to convey in the target language the original intent of a message in a source language, this study intends to examine how the translator assists the target readers in understanding the source text. One of the ways through which the translator reaches out to the target readers is through the use of notes in the translation. Fabretti (2016), who explored the use of notes in manga scanlation or unauthorized translations of manga, underlines the importance of translation notes or $\mathrm{T} / \mathrm{N}$ in the comic in the following:

In Translation Studies, the presence of $\mathrm{T} / \mathrm{N}$ in a translation is considered particularly significant because they clearly indicate what features of the source text the translator considered important for the comprehension of the text and therefore necessary to retain or explain. (Fabretti, 2016, p. 86).

Genette (1997) defines a note as "a statement of variable length (one word is enough) connected to a more or less definite segment of text and either placed opposite or keyed to this segment" (p. 319). Notes may be authorial/autographic (written by the author), allographic (written by an editor or translator) or actorial (written by the character or subject of a text) (Genette, 1997). While notes are clearly not considered as part of the main text, they are nonetheless significant in translated work. This is evident in the various studies which have looked at this paratextual element in the context of translation, for instance, in the study by Paloposki (2010), Toledano Buendía (2013), Tian (2014), Sanchez Ortiz (2015), Luo and Zhang (2018), and Haroon (2019). In spite of the fact that notes are significant in translation, very little research, with the exception of Fabretti's (2016), has looked into the use of this paratextual element in translated manga. In view of this, this study intends to explore how the translator reaches out to the target readers via allographic notes in the translation. More specifically, the aims of the study are: (1) to examine the type of notes used in the selected translations of Japanese manga into Malay, (2) to determine the items in the Japanese manga which required clarification in the form of notes, and (3) to examine the differences in the type of notes employed in the Malay and English translations.

In the context of translation, notes are "a means by which the translator or other mediators may bring the text closer to the reader" (Kovala, 1996 , p. 125). Notes, therefore, are a form of intervention on the part of the translator and can be seen as a way for the translator to reach out to the readers. Newmark (1988) lists "notes, additions, glosses" among the translation procedures which the translator has at his/her disposal when dealing with translation problems. He adds that the requirement of the target readership is the factor which determines what kind of notes are added by the translator in the translation. In other words, the translator may provide notes in the translation based on the assumed needs of the readers. Thus, the notes added may be cultural, i.e. they help explain the differences between the source and target cultures, or technical, i.e. they help explain a technical term, or linguistic, i.e. they help explain the peculiarities of language (Newmark, 1988).

In his study of the scanlation of manga into English, Fabretti (2016) identifies a number of elements in manga which required the use of notes by the translator. The elements are: (1) extralinguistic references. i.e. "material cultural items of various kinds that are expressed through the textual elements of manga" (p. 91); (2) intralinguistic references, i.e. "references to language variation, slang, dialects, etc." (p. 94); (3) borderline features, i.e. "culture-specific references that cross-cut both extralinguistic and intralinguistic categories" (p. 96); and (4) visual features, i.e. elements of Japanese culture which are expressed through visual means.

In terms of their location, notes added by the translator may appear in many different places, for instance, within the text, at the bottom of the page, at the end of a chapter, or at the end of a book (Newmark, 1988). Pym (2004) echoes the views of Newmark (1988), and points out that "notes can be at the bottom of the page, the end of the chapter, the end of the book, in a supplementary glossary or even in specialized dictionaries" (p. 100). The views of both Newmark (1988) and Pym (2004) perhaps, however, are more applicable to book translations. In manga scanlation, as evident in the study by Fabretti (2016), notes may also be added in the gutter. 
Taking into account the available literature on where and how notes are used in translation, this study aims to examine the use of notes in the translation of manga into Malay and English in Malaysia.

\section{METHOD}

This study adopts a qualitative content analysis approach to analyse the use of notes by translators in the translation of Japanese manga into Malay and English. It is crucial to point out that this study departs from Fabretti's (2016) study in that it focuses on notes in official manga translation and not in unauthorised manga translation as in Fabretti's case. In addition, this study intends to examine the different kinds of notes which are incorporated in the translations, as opposed to Fabretti (2016), who focused on notes in the gutter.

The corpora consist of six manga from two series which are published in Japanese, and the translations in both Malay (M) and English (E) for each of the manga. The source texts and their translations are shown in Table 1.

Table 1

The Corpora of the Study

\begin{tabular}{|c|c|c|c|}
\hline & Title of Japanese manga & Malay translation $(\mathrm{M})$ & English translation (E) \\
\hline 1. & 君の名は01 (2016) & NAMAMU...01 (2016), & your name. 01 (2017), \\
\hline 2. & 君の名は02 (2016) & NAMAMU...02 (2017), & your name. 02 (2017) \\
\hline 3. & 君の名は03 (2017) & NAMAMU...03 (2017) & your name. 03 (2017) \\
\hline 4. & よつばと! 1 (2003) & Yotsuba\&! 1 (2017) & Yotsuba\&! 1 (2018) \\
\hline 5. & よつばと! 2 (2004) & Yotsuba\&! 2 (2018) & Yotsuba\&! 2 (2018) \\
\hline 6. & よつばと! 3 (2004) & Yotsuba\&! 3 (2018) & Yotsuba\&! 3 (2018) \\
\hline
\end{tabular}

The first three Japanese source texts from the first series are published by Kadokawa Corporation while the other three from the second series are published by ASCII Media Works. The translations in Malay and English are all published by Kadokawa Gempak Starz. Both the translations in Malay and English are chosen for analysis in order to investigate whether there is a difference in the use of notes in translations into the different languages in Malaysia.

The two series are chosen mainly for their popularity. Both titles have been translated into many different languages and sold worldwide. 君の 名は in particular was created based on an anime with a similar title, which has gained a huge global following. In addition to that, both 君の名は and つばと! also contain a number of Japanese cultural elements which are assumed to pose a problem if they are to be translated into a different language and a different social context. As such, the series lend themselves particularly well to the analysis of culture-related translation problems.

The first aim of the study is to identify the form of notes used in the selected translations of Japanese manga into Malay and English. To do so, this study takes into consideration the available literature on the location of notes in translated works by Newmark (1998), Pym (2004) and Fabretti (2016). The second aim of the study is to determine the items in the Japanese manga which required clarification in the form of notes. Therefore, for each type of note that is identified, the item for which the note is provided is categorised based on the classification that emerges from the data itself. Also, the differences in the type of notes employed in the Malay and English translations are discussed.

\section{FINDINGS AND DISCUSSION}

The analysis carried out on the source texts and their translations shows that in the context of Malay and English translations of manga in Malaysia, the translators made use of three different types of notes in the translation: (i) notes on the image, (ii) notes in the gutter, and (iii) notes at the end of the book. The three types of notes are incorporated in the translation in order to explain various elements of the manga, as can be seen in Table 2 .

In the following, the three types of notes are discussed, and examples are provided to illustrate the use of each type of note and the elements for which the notes are provided. In the images shown in each of the example, the Japanese source text is marked (a), the Malay translation (b), and the English translation (c).

\section{Notes on the image}

One of the ways through which notes are used is by adding them on the images themselves. The analysis shows that notes are added by the translator on the image in order to explain the following elements: (a) giongo/gitaigo, (b) inscriptions, and (c) cultural reference.

\section{Giongo/gitaigo}

Giongo (擬音語) and gitaigo (擬態語) are types of Japanese onomatopoeia. Giongo is used to refer to words which resemble or represent sounds. Gitaigo, meanwhile, refers to words which represent certain actions, behaviours or conditions.

Figure 1(a) depicts four characters who are all looking at Yotsuba, an active and curious child who 
is the lead character in よつばと! (Yotsubato!). Yotsuba has released the cicadas that she caught and the other characters are looking at her in disbelief, as the insects fly all over the place. The Japanese word ブア $(b u a)$ is printed in straight thick bars, overlapping the image in the panel. In this instance,
ブア (bua) does not carry a specific meaning but serves as a giongo/gitaigo to describe the sound or the act of the cicadas flying. The fact that the word ブア $(b u a)$ is printed in straight thick bars conveys the idea that there is a loud and harsh sound generated by the cicadas as they fly across the room.

Table 2

Notes added in the Malay and English translations of selected Japanese manga

\begin{tabular}{|c|c|c|c|c|c|c|c|c|c|c|c|c|c|}
\hline \multirow{2}{*}{ Type of notes } & \multirow[b]{2}{*}{ Elements } & \multicolumn{2}{|c|}{$\begin{array}{c}\text { 君の名 } \\
\text { は01 }\end{array}$} & \multicolumn{2}{|c|}{$\begin{array}{c}\text { 君の名は } \\
02\end{array}$} & \multicolumn{2}{|c|}{$\begin{array}{c}\text { 君の名 } \\
\text { は03 }\end{array}$} & \multicolumn{2}{|c|}{$\begin{array}{c}\text { よつばと } \\
! 1\end{array}$} & \multicolumn{2}{|c|}{$\begin{array}{c}\text { よつば } \\
\text { と!2 }\end{array}$} & \multicolumn{2}{|c|}{$\begin{array}{c}\text { よつば } \\
と ! 3\end{array}$} \\
\hline & & $\mathrm{M}$ & $\mathrm{E}$ & $\mathrm{M}$ & $\mathrm{E}$ & $\mathrm{M}$ & $\mathrm{E}$ & $\mathrm{M}$ & $\mathrm{E}$ & $\mathrm{M}$ & $\mathrm{E}$ & $\mathrm{M}$ & $\mathrm{E}$ \\
\hline \multirow[t]{3}{*}{ Notes on the image } & Giongo/Gitaigo & 20 & 19 & 12 & 12 & 10 & 9 & 14 & 14 & 8 & 8 & 4 & 4 \\
\hline & Inscription & & & & & & & 2 & 2 & 4 & 5 & 3 & 4 \\
\hline & $\begin{array}{l}\text { Cultural } \\
\text { reference }\end{array}$ & & & & & & & & & 1 & 1 & 1 & 1 \\
\hline \multirow[t]{5}{*}{ Notes in the gutter } & Wordplay & & & & & & & 2 & 2 & & & & \\
\hline & Cultural reference & 5 & 6 & & & & 3 & & & 1 & & & \\
\hline & Technical term & & & & 1 & & & & & & & 1 & \\
\hline & Giongo/Gitaigo & 1 & 1 & & & & & & & 3 & 7 & 5 & 5 \\
\hline & Inscription & & & & & & & & & & & 2 & 1 \\
\hline $\begin{array}{l}\text { Notes at end of the } \\
\text { book }\end{array}$ & Honorifics & & 1 & & 1 & & 1 & & & & & & \\
\hline
\end{tabular}

Figure 1

(a)よつばと! 1 (2003, p. 198); (b) Yotsuba\&! 1 (2017, p. 198); (c) Yotsuba\&! 1 (2018, p. 198)
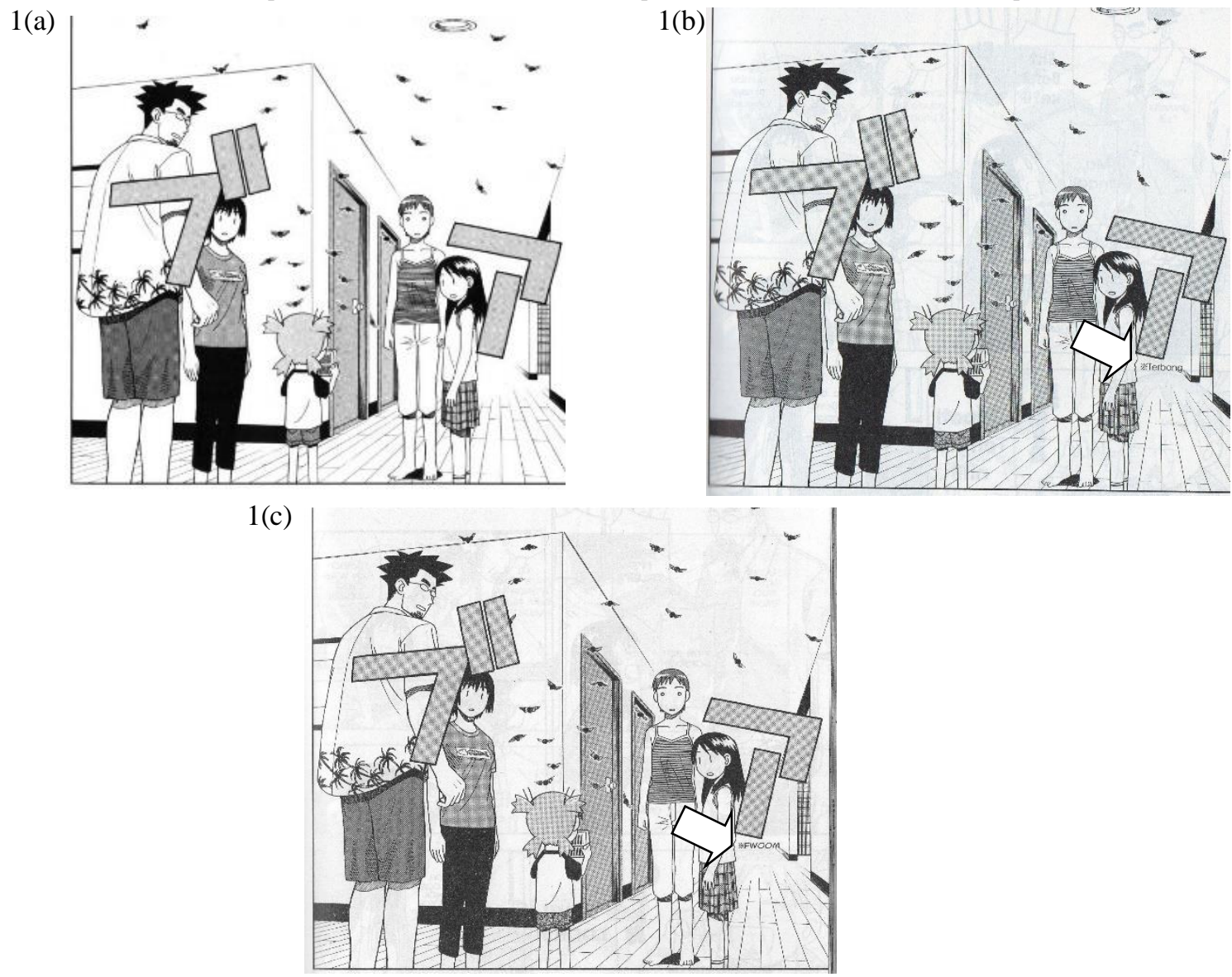

In the corresponding panels in Malay (Figure 1(b)) and English (Figure 1(c)), the Japanese word ブア $(b u a)$ is retained in the exact same way. A note, however, is added on the image by the translator of both the Malay and English translations. In the Malay translation, the word 
'terbang' (lit. flying) is added on the image, perhaps as a way of conveying the meaning of ブア (bua), although ブア $($ bua $)$ does not literally mean 'flying'. The translator of the English text, meanwhile, employs the use of an approximate onomatopoeia, 'FWOOM' to convey the sound or the action of the cicadas, as there is no onomatopoeia in English to represent the sound or the action.
It must also be noted that the translator adds notes on the image only in instances where the giongo/gitaigo is prominent and overlaps the image in the panel in a substantial manner. For giongo/gitaigo which are not as prominent, as can be seen in Figure 2, they are normally deleted and replaced with a word in the target text.

\section{Figure 2}

(a) 君の名は01 (2016, p. 53); (b) NAMAMU...01 (2016, p. 53); (c) your name. 01 (2017, p. 53)

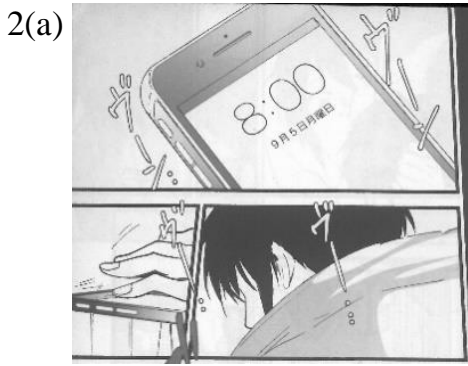

In this example, the giongo/gitaigo ヴーン (vuun) is used to convey the message that the phone is vibrating. In the Malay translation, the onomatopoeia is deleted and replaced with the Malay verb 'getar' (lit. vibrate). The onomatopoeia is also deleted in the English translation, but it is replaced with an approximate onomatopoeia in
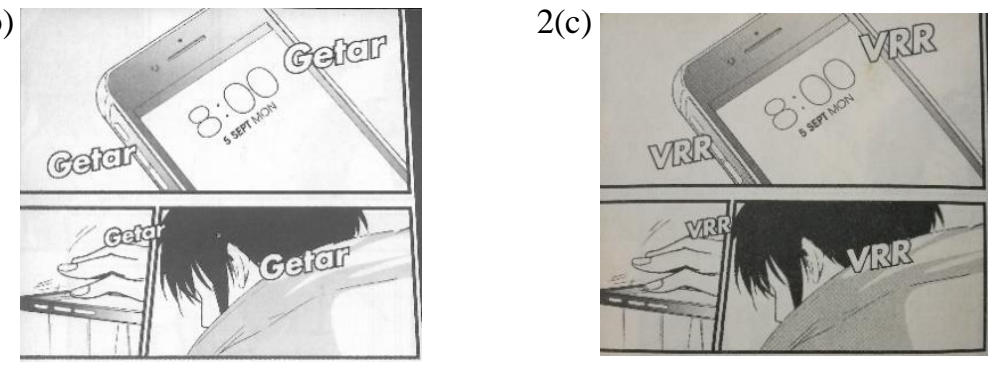

English, 'VRR', which is also able to convey the meaning as intended in the Japanese source text.

\section{Inscription}

Besides being used to explain giongo/gitaigo, notes are also added on the image by the translators in order to clarify the meaning of Japanese inscriptions, as shown in the panel in Figure 3.

\section{Figure 3}

(a)よつばと! 1 (2003, p. 93); (b) Yotsuba\&! 1 (2017, p. 93); (c) Yotsuba\&! 1 (2018, p. 93)

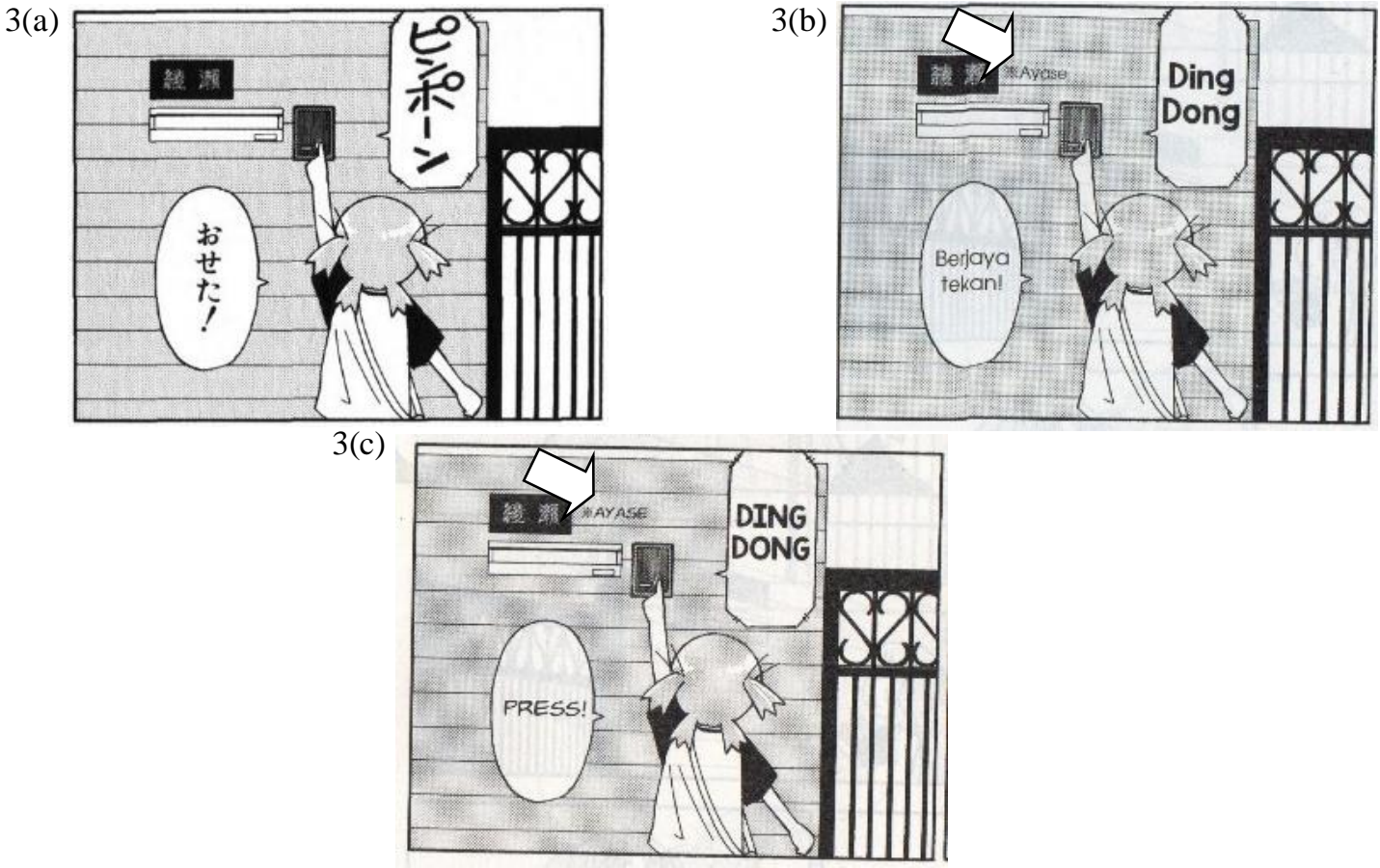

Figure 3(a) shows Yotsuba pressing the doorbell of a neighbour' house. The story in this panel is related to an earlier panel which shows Yotsuba wanting to press the doorbell of a house bearing a sign with the inscription 上村 (Uemura), to indicate the surname of the family living in the house. Because of her height, she is unable to press the bell. She, however, enlisted the help of her 
neighbour 風香 (Fuuka), who was passing by, to help her press the doorbell of the house of the 上村 (Uemura) family.

In Figure 3(a), Yotsuba is shown pressing the doorbell of Fuuka's house, which bears a sign with the inscription 綾瀬 (Ayase), to indicate Fuuka's surname. It can be seen that the Japanese inscription 綾瀬 is retained in both the Malay and English translations. A note, however, is added, on the image in both the translations. In this instance, the note is in the form of a transliteration of the Japanese inscription, i.e. 'Ayase'. The note functions not only to tell the readers the pronunciation of Fuuka's surname but also to clarify that Yotsuba wanted to press the doorbell of house of the Ayase family and not the doorbell of the house of the Uemura family. The note, thus, helps avoid confusion on the part of the readers.

\section{Cultural reference}

Notes are also added on the image by the translators in order to clarify the meaning of certain culturespecific references, as shown in Figure 4.

\section{Figure 4}
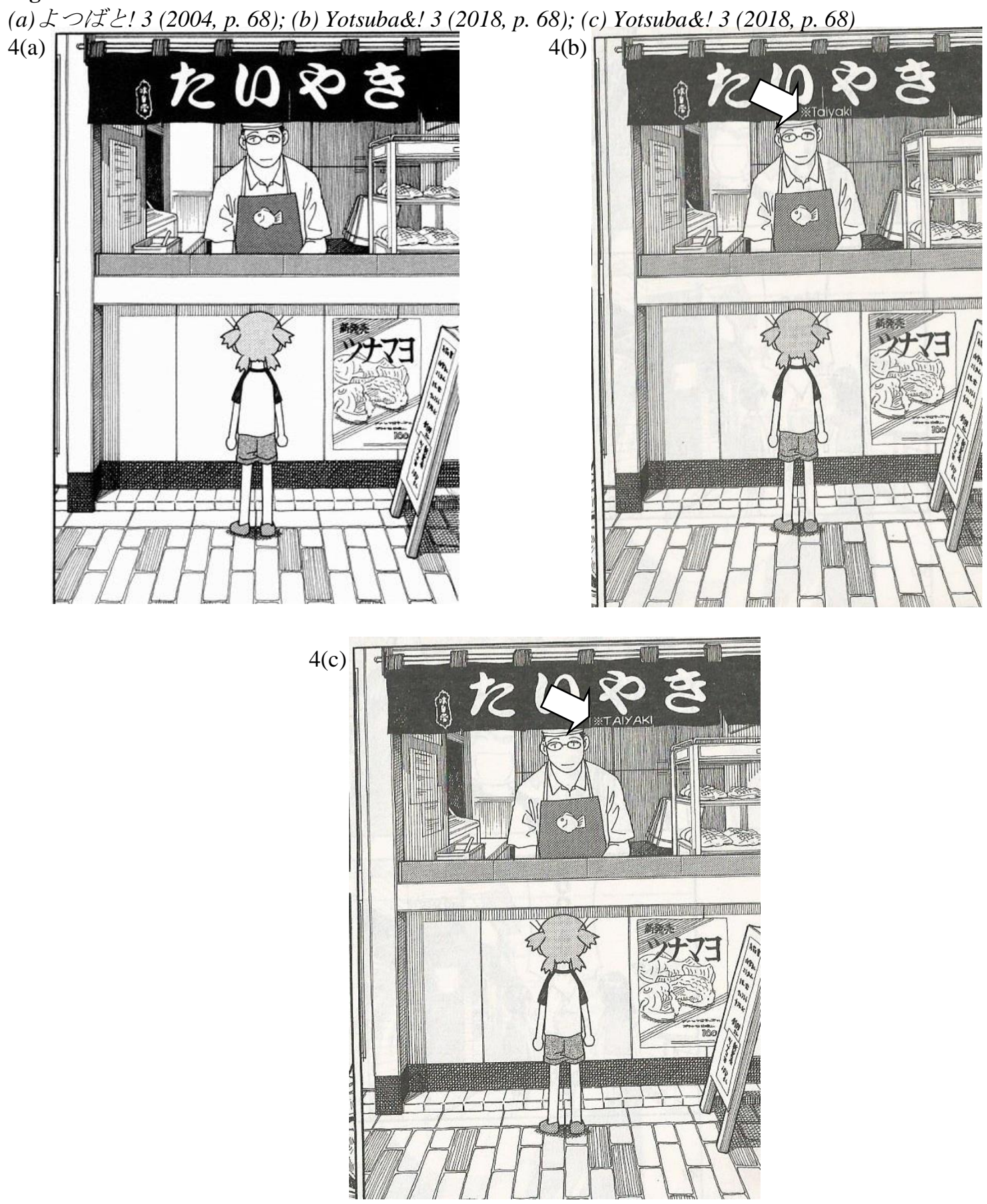
In Figure 4(a), Yotsuba is depicted standing in front of a たいやき (taiyaki) shop, as evident from the shopfront signage shown. たいやき is a fishshaped pancake filled with bean jam (Weblio, n.d.). The fact that the shop is selling 'taiyaki' is clear from the image of 'taiyaki' shown not only in the food display unit but also on the poster of the shop counter and on the apron worn by the seller.

In the corresponding panels in Malay and English, the same image is retained, including the Japanese word たいやき on the shopfront signage. A note, however, is added on the image by the translator of both the Malay and English translations. The added note is the word 'taiyaki', which is the transliteration of the Japanese word $た$ いやき.

It must be noted that no explanation is provided for the note that is added. This is most likely due to the popularity of the food item in Malaysia. Readers, therefore, are assumed to require no explanation for the word 'taikayi'. It must also be noted that there is a slight difference in terms of the typeface used for the note that is added. The Malay translation employs the use of sentence case while the English translation uses uppercase. The use of uppercase in the note in the English translation is most likely in line with conventions in western comics (cf. McCloud, 2006, pp. 144-145).

\section{Notes in the gutter}

Another way notes are used in the translations is by adding them in the gutter. Based on the analysis carried out, notes which are added in the gutter are used to explain the following: (a) wordplay, (b) cultural reference, (c) technical term, (d) giongo/gitaigo, and (e) inscription.

\section{Wordplay}

Some of the notes are added in the gutter in order to explain how words in Japanese are manipulated in the source texts in order to achieve a comic effect. This can be seen, for instance in the panels in Figure 5. In this particular example, the wordplay is conveyed through two different panels on separate pages. Thus, the two panels from the Japanese source texts are marked 5(a1) and 5(a2) respectively. Their translations in Malay are marked as 5(b1) and 5(b2), while the English translations are marked as 5(c1) and 5(c2), as can be seen in the following:

\section{Figure 5}

(a1) and (a2)よつばと! 1 (2003, p. 210 \& p. 212); (b1) and (b2) Yotsuba\&! 1 (2017, p. 210 \& p. 212); (c1) and (c2) Yotsuba\&! 1 (2018, p. $210 \&$ p. 212)

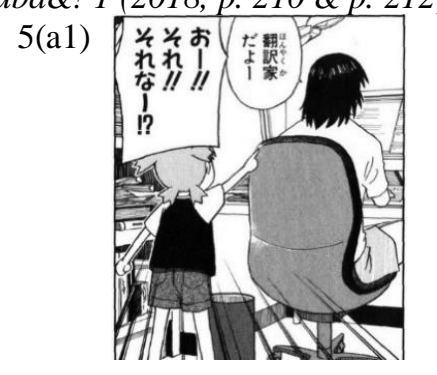

$5(\mathrm{~b} 1)$

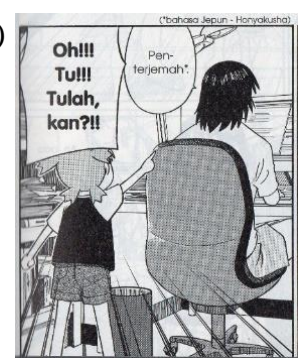

5(c1)

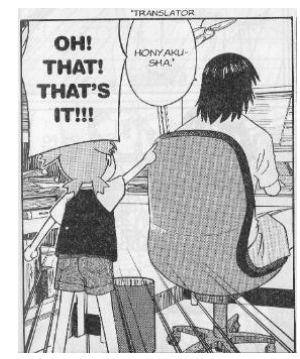

$5(\mathrm{a} 2)$

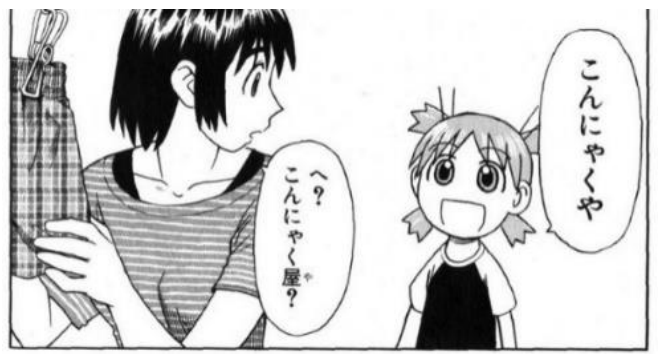

$5(\mathrm{~b} 2)$

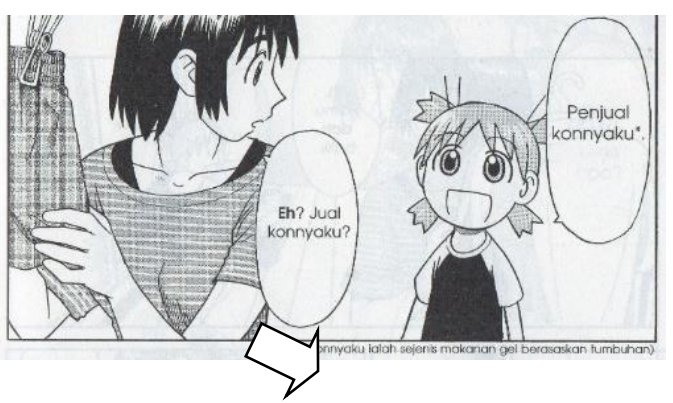

$5(\mathrm{c} 2)$

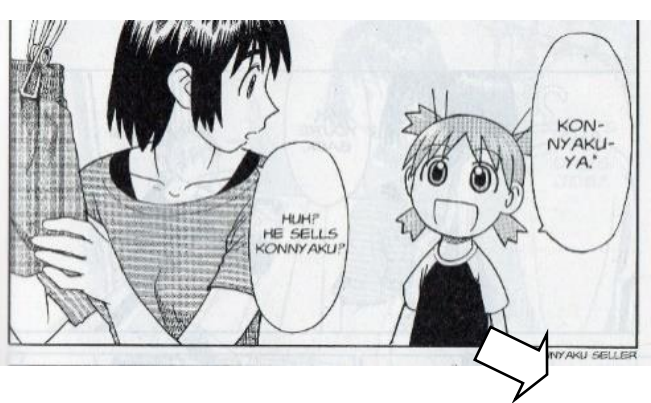


In Figure 5(a1), the lead character, Yotsuba, asks her father about his occupation, after being asked the question by her neighbour. Her father then replies that he works as a 翻訳者 (honyakusha), which means 'translator' (Weblio, n.d.). Figure 5(a2) then shows Yotsuba giving her neighbour 風 香 (Fuuka) the information. Unfortunately, instead of telling Fuuka that her father works as a 翻訳者 (honyakusha), she mispronounced the word and tells her that he works as a こんにやくや(konnyakuya), which means a 'konnyaku' seller (Weblio, n.d.), where 'konnyaku' is 'a jelly-like food made from the starch of the devil's tongue' (Weblio, n.d.). The play on the words 翻訳者(honyakusha) and こんに や や (konnyakuya) in the Japanese manga is therefore intended to create a humorous effect.

In the Malay translation as shown in Figure 5(b1), the speech bubble shows Yotsuba's father telling her that he works as 'penterjemah' (lit. translator). Therefore, the original Japanese word 翻 訳者 is translated directly into Malay. An asterisk, however, is placed after the word 'penterjemah' to call the reader's attention to the fact that there is additional information in the gutter relating to the word. Through the note '(*bahasa Jepun Honyakusha)', which is placed in brackets in the gutter at the top of the panel, the readers are made aware of the fact that the pronunciation of the Japanese word originally used in the source text is 'honyakusha'. Here, only the transliteration of the original Japanese word is provided. Similarly, as shown in Figure 5(b2), the Japanese word こんにや $<や$ is translated directly into Malay in the speech bubble as 'penjual konnyaku', with a note added in brackets in the gutter to explain to the readers that 'konnyaku ialah sejenis makanan gel berasaskan tumbuhan)' (lit. konnyaku is a jelly-like plant-based food). The note in the gutter therefore functions to explain the pronunciation of the original Japanese word and the meaning, so that the humourous effect can also be felt in the Malay translation.

A slightly different approach, however, is taken in the English translation. As seen in Figure $5(\mathrm{c} 1)$, the word 'HONYAKUSHA', which is the transliteration of 翻訳者, is placed directly in the speech bubble, while its meaning, 'TRANSLATOR' is placed in the gutter. Likewise, in Figure 5(c2), the word 'KONNYAKUYA', which is the transliteration of こんにやくや, is placed directly in the speech bubble, while its meaning, 'KONNYAKU SELLER' is placed in the gutter. The wordplay and its intended effect are therefore much clearer in the English translation. The meaning of 'konnyaku', however, is not explained in the English translation. As a result, readers may perhaps only understand that Yotsuba has mispronounced her father's job. They may not be able to understand the actual meaning of 'konnyaku'.

We can see that there is a slight difference between the Malay and English translations. In the Malay translation, the transliteration of the Japanese word is placed in the gutter with explanation. In contrast, the transliteration of the source text is placed in the speech bubble in the English translation. Nevertheless, the notes provided in both translations function to retain and convey the form of humour conveyed through the mispronunciation of the Japanese word.

\section{Cultural reference}

We have seen previously the use of notes on the image in order to explain the meaning of a culturespecific reference. The translator also resorts to notes in the gutter in order to explain cultural elements in the Japanese manga, as seen in Figure 6.

\section{Figure 6}

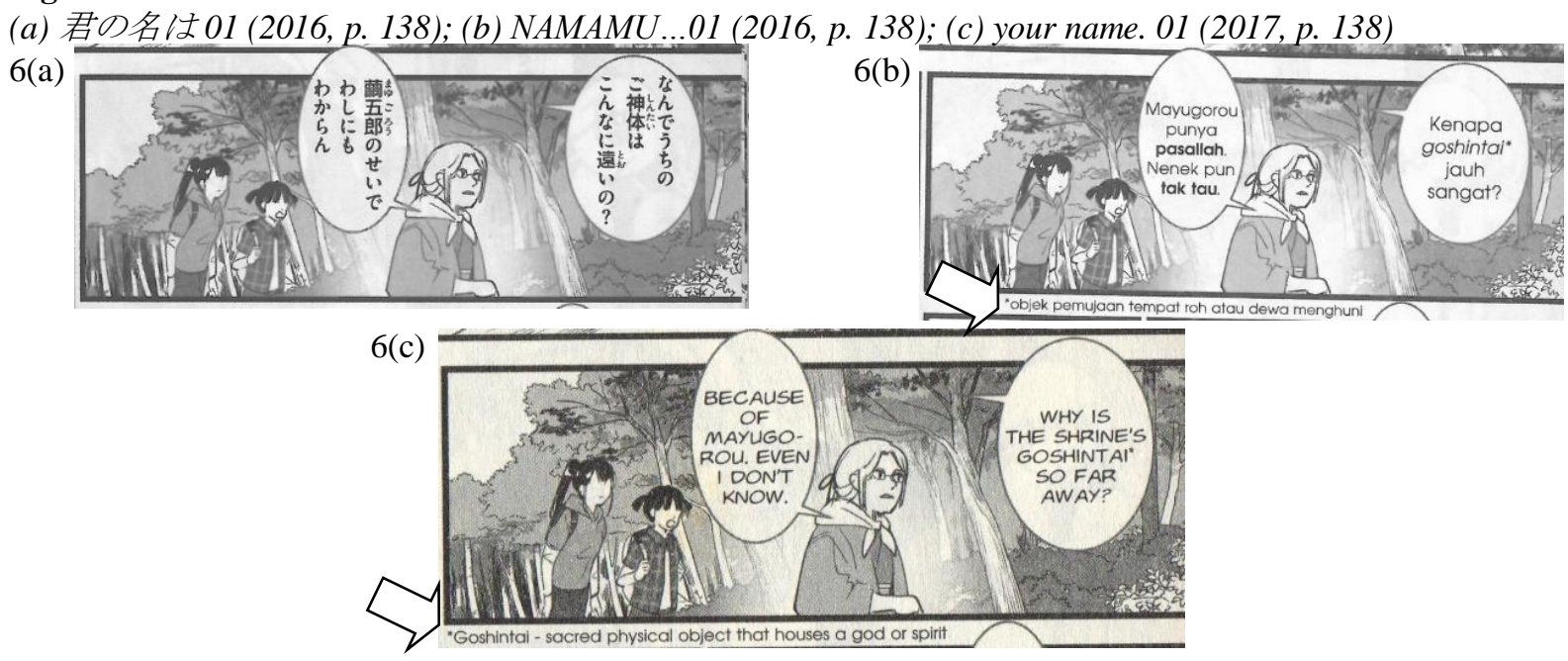

In this example, the Japanese source text contains a Shinto religious term, ご神体 (goshintai), which refers to the object of worship believed to contain the spirit of a deity' (Weblio, n.d.). According to Japanese beliefs, the Shinto 'God' or divine spirits are present in elements of nature such 
as trees, mountains, rivers, lakes, waterfalls and stones. In this panel, Mitsuha, her sister and their grandmother are making their way across the jungle and the mountains to the cave where the ご神体 (goshintai) or the object of worship is located.

In the Malay translation, the Japanese word $こ$ 神体 is transliterated as 'goshintai', which is placed directly in the speech bubble. The word 'goshintai' is in italic typeface and is followed by an asterisk. A note is added in the gutter, explaining that 'goshintai' is 'objek pemujaan tempat roh atau dewa menghuni' (lit. the object of worship where the spirit or god dwells'. The same approach is taken in the English translation, in which ご神体 is also transliterated as 'GOSHINTAI' in the speech bubble. The transliteration is also followed by an asterisk. The note added in the gutter explains the meaning carried by the word 'Goshintai', which is a 'sacred physical object that houses a god or spirit'.

\section{Technical term}

Notes are also added by the translators in the gutter in order to clarify the meaning of a technical term, as seen in Figure7.

\section{Figure 7}

(a) 君の名は02 (2016, p. 54); (b) NAMAMU...02 (2017, p. 54); (c) your name. 02 (2017, 54)

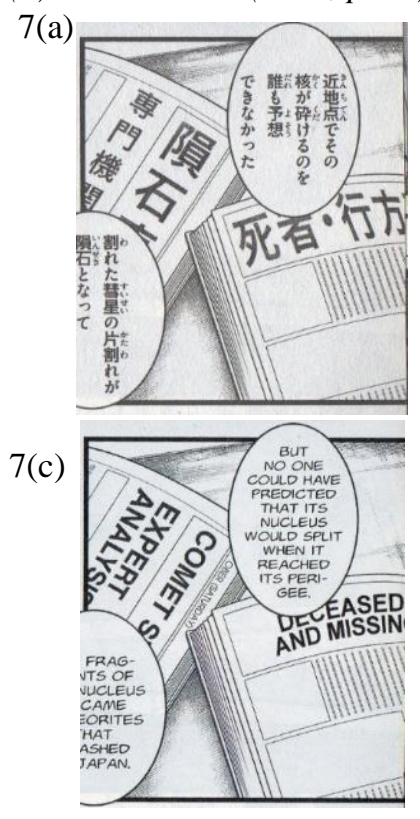

Figure 7(a) shows two documents - a news report on a comet incident and a list of the names of victims who died or are missing in the incident. The dialogue in the first speech bubble tells the readers that the nucleus of the comet split when it reached 近地点 (kin chi ten) and this led to the explosion that destroyed the town. 近地点 is a technical term in the field of astronomy, which means 'perigee' (Weblio, n.d.). Its English equivalent is 'perigee', which refers to "the point in the orbit of the moon or a satellite at which it is nearest to the earth" (Perigee, n.d.).

In the Malay translation, the term 近地点 is translated as 'perigi'. In Figure 7(b), an asterisk is placed in front of the word 'perigi' to indicate that a note is added to explain the meaning of the word. The note is added in the gutter and it tells the readers that 'perigi' refers to 'keadaan sesuatu objek apabila berada paling hampir dengan bumi' (lit. the condition of an object when it is closest to the earth). The note added serves not only to explain the technical term but also perhaps to avoid confusion, as the word 'perigi' also carries another meaning in
Malay, i.e. a well. In the English translation, the English equivalent of 近地点 (kin chi ten) is used, i.e. 'perigee'. No explanation, however, is given, for the word 'perigee'. The translator most likely assumes that the readers require no assistance where the word 'perigee' is concerned due to that fact that it is an existing term in English, despite being technical in nature.

Notes are also added in the gutter by the translators in order to explain the meaning of giongo/gitaigo and to clarify the meaning of Japanese inscriptions. Examples of notes in the gutter for these two aspects and further explanation regarding the notes are not provided because they are similar to the examples in Figure 1 and Figure 3, the only difference being the position of the notes.

\section{Notes at the end of the text}

Finally, besides adding notes on the image and in the gutter, the translator also resorts to adding notes at the end of the text. This can be seen in Figure 8, where notes are added at the end to explain the use of Japanese honorifics. 


\section{Figure 8}

(a) 君の名は01 (2016, p. 67); (b) NAMAMU...01 (2016, p. 67); (c) your name. 01 (2017, p. 67); (d) your name. 01 (2017, p. 173).
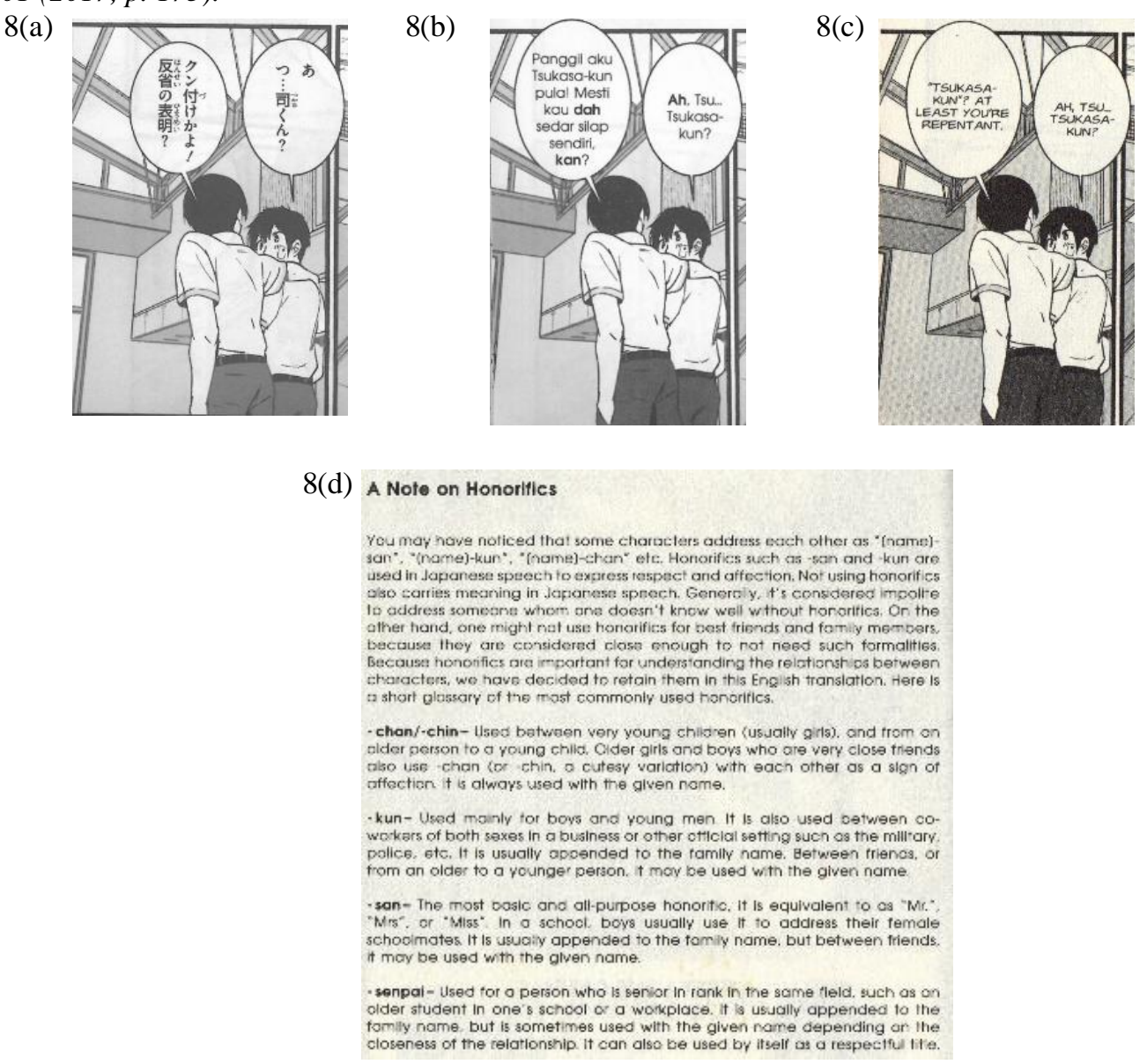

In the Japanese language, honorifics are important to show respect and to indicate relationship as well as gender. The manga 君の名は depicts two lead characters, Taki and Mitsuha, who exchange their bodies from time to time. Taki's manner of speaking is more masculine and as such he does not use honorifics to greet his friends. However, when Mitsuha, the female lead, exchanges body with Taki, Mitsuha uses honorifics to greet Taki's friend. This has led to a number of awkward exchanges.

In the panels which precede Figure 8 , a character by the name of Tsukasa is shown calling Taki continuously because Taki is late for school. In Figure 8, Tsukasa is shown approaching Taki when he arrives at school. Based on what Tsukasa says, Mitsuha (who is inside Taki's body) suddenly realises that the person talking to her is Taki's friend who called her earlier. Mitsuha, surprised by the realisation, then responds by saying “あ つ...司く ん?" (lit. Ah, Tsu... Tsukasa-kun?), using the honorific 'kun' to refer to Taki's friend. Tsukasa, as a result, is surprised by what he sees as Taki's extreme politeness. Tsukasa then replies by saying “ クン付けか上! 反省の表明?” (lit. You use “kun' to call me! Does this mean you know you have done something wrong?'). Tsukasa, who does not know that Taki has exchanged his body with Mitsuha, assumes that Taki is addressing him using the honorific ' $k u n$ ' because of the guilt he feels for not replying Tsukasa's message.

It can be seen from this example that the honorific ' $k u n$ ' is retained in both the English and Malay translations. The meaning of the honorific is explained, but only in the English translation. A note entitled "A Note of Honorifics" (Figure 8(d)) is attached at the end of the English translation to explain the function of honorifics in the Japanese language and to show a number of honorifics which are used frequently in the manga. Thus, the note at the end serves to explain one aspect of Japanese culture.

It must be noted that the example shown is the only instance in which the Japanese honorific is retained. Other Japanese honorifics used in the manga are either omitted or substituted with another word. For instance, the honorific 先輩 (senpai) is substituted with the word 'senior' in the Malay translation.

The analysis carried out shows that regardless of where they are located, notes which are added in the Malay and English translations of the Japanese 
manga all serve the same purpose, that is, to provide the necessary information to the readers so as to enhance their understanding of the text. However, as seen in Table 2, not all the elements which require clarification are related to Japanese cultural references. Notes are also added to explain a technical term and an inscription (綾瀬 /Ayase), both of which have little to do with Japanese culture.

Secondly, the analysis also reveals that an element which require clarification or explanation in the Japanese manga is not always treated in the same way. As seen in Table 2, notes which added to explain the Japanese giongo/gitaigo are sometimes placed on the image and at other times placed in the gutter. The same can be said for notes added to explain certain inscriptions and culture-specific elements.

Finally, the analysis also points to the fact that the Malay and English translators at times differ in terms of how they deal with certain elements in the text, despite the fact that the translations are both published in Malaysia by the same publisher. For instance, notes added in the Malay translation uses a typeface that is different from that used in the English translation. Another example is the use of notes at the end of the English translation to explain the use of Japanese honorifics. It can be seen that the Malay translation decided to dispense with the note altogether.

\section{CONCLUSION}

This study tried to examine the type of notes used in selected translations of Japanese manga into Malay and English, and to determine items in the Japanese manga which required clarification and for which notes are provided. The study found that the translators made use of three types of notes in the translation, i.e. notes on the image, notes in the gutter, and notes at the end of the text. These three types of notes are used as a way of explaining elements in the manga such as giongo/gitaigo, inscriptions, culture-specific elements, wordplay, technical terms and honorifics.

The findings of this research, particularly with respect to how notes are used in translated manga into Malay and English, appear consistent with Newmark's (1988) and Fabretti's (2016) opinion regarding the nature of the notes which are added in translation. All the notes are explanatory in nature and supplement the translated text by providing the target readers with relevant information and clarification necessary for total and complete understanding of the translated manga. This study, however, is based only on a small number of translations. Future studies could perhaps fruitfully explore the issue of the function of notes in manga translation further, in order to see whether notes in manga translations perform other functions besides explanatory.
One important contribution of this research is that it reveals a number of practical approaches taken in the translation of manga into Malay and English in Malaysia. Notes, thus, may appear not only in the gutter, as in Fabretti's (2016) study, but also on the image and at the end of the translated text. Future research could therefore be carried out to explore other types of notes which are introduced by translators in translated manga. These findings can then be translated into practical guidelines which can be helpful to manga translators.

This study is also limited in that it focused on only one paratextual element, i.e. notes, in order to see how translators use them to reach out to their readers. Because of the paucity of research in the area of paratextual elements in translated manga, it is not clear whether there are other means through which translators provide assistance to their readers. As such, one direction for further research is to explore other paratextual elements in a larger corpus of translated manga in order to see how manga translators reach out to their readers via these other paratextual elements.

\section{REFERENCES}

Brienza, C. (2009). Paratexts in translation: reinterpreting "manga" for the United States. International Journal of the Book, 6(2), 13-19. https://doi.org/10.18848/14479516/cgp/v06i02/36733

Chow, Y. F., \& Che Omar, H. (2019). Penterjemahan giongo/gitaigo dalam manga Jepun Kimi No Na Wa. Jurnal Bahasa, 19(2), 307-328. https://doi.org/10.37052/jb.19(2)no6

Ding, N. (2014). An analysis of the accuracy and translation strategies of Kanji translation into Chinese in Meitantei Konan (Mingzhentan Kenan). [Master's thesis]. Universiti Sains Malaysia.

Fabretti, M. (2016). The use of translation notes in manga scanlation. Transcultural: A Journal of Translation and Cultural Studies, 8(2), 86-104. https://doi.org/10.21992/t9ss57

Fujimura, N. (2012). 音のない音を文字にするこ とのジレンマーマンガにおける擬態語表現 の翻訳分析から[The dilemma of translating mimetic words that do not involve sound: An analysis of the translation of mimetic expressions in manga]. 文化環境研究, 6, 6271. https://ci.nii.ac.jp/naid/110009005452

Genette, G. (1997). Paratexts: Thresholds of interpretation (J.E Lewin, Trans.). Cambridge University Press.

Haroon, H. (2019). The use of footnotes in the Malay translation of $A$ Thousand Splendid Suns. Translation \& Interpreting, 11(1), 130146.

https://doi.org/10.12807/ti.111201.2019.a08 
Inose, H. (2010). マンガにみる擬音語・擬態語の 翻訳手法 [The translation procedures of onomatopoeia and mimetic words in manga]. 通訳翻訳研究への招待, 10, 161-176. https://ci.nii.ac.jp/naid/40017656413

Japan Book Publishers Association. (2017). An Introduction to Publishing in Japan 20172018. [Booklet]. Japan Book Publishers Association.

Jüngst, H. E. (2004). Japanese comics in Germany. Perspectives: Studies in Translatology, 12(2), 83-105. https://doi.org/10.1080/0907676X.2004.99614 93

Kadokawa Corporation. (2015, November 5). マレ シアArt Square Group の株式取得および同 国政府機関InvestKLによる事業支援に関 するお知らせ[News release regarding Acquisition of shares of Art Square Group, Malaysia and business support by InvestKL]. Retrieved April 3, 2020, from https://ir.kadokawa.co.jp/topics/20151105_t4s hx.pdf

Kovala, U. (1996). Translations, paratextual mediation, and ideological closure. Target, 8(1), 119-147. https://doi.org/10.1075/target.8.1.07kov

Luo, T., \& Zhang, M. (2018). Reconstructing cultural identity via paratexts: A case study on Lionel Giles' translation of The Art of War. Perspectives, 26(4), 593-611. https://doi.org/10.1080/0907676x.2017.140165 0

Mamat, R., Abd Rahim, N., Nik Muhamad Affendi, N. R., \& Abdul Rashid, R. (2019).

Perkembangan komik dan animasi: Satu kajian perbandingan antara Melayu dan Jepun. Jurnal Komunikasi: Malaysian Journal of Communication, 35(2), 260-276. https://doi.org/10.17576/jkmjc-2019-3502-16

Mamat, R., Abdul Halim, H., Mansor, N. S., \& Abd Rahim, N. (2016). Plot penceritaan dalam shojo manga. Jurnal Kemanusiaan, 25(1), 101109.

Mamat, R., Abdul Rashid, R., Abdul Halim, H., \& Mansor, N. S. (2018). Penggunaan manga dan anime sebagai media pembelajaran dalam kalangan pelajar bahasa Jepun di Universiti Awam Malaysia. Jurnal Komunikasi: Malaysian Journal of Communication, 34(3), 298-313. https://doi.org/10.17576/jkmjc-20183403-18

Mamat, R., Mansor, N. S., Abdul Halim, H., \& Abd Rahim, N. (2015). Manga dan dojinshi Malaysia: Persamaan dan perbezaan ciri-ciri luaran karikatur. Jurnal Komunikasi: Malaysian Journal of Communication, 31(2), 477-492. https://doi.org/10.17576/jkmjc-20153102-27
McCloud, S. (2006). Making comics: Story telling secrets of comics, manga and graphic novels. HarperCollins Publishers.

Mohd Hanif, H. H. (2014). Satu analisis terjemahan humor dalam buku komik Crayon Shin Chan. [Master's thesis, Universiti Sains Malaysia].

Newmark, P. (1988). A textbook of translation. Prentice Hall.

Ningsih, E., Emzir, E., \& Hidayat, R.S. (2018). Dynamic equivalence assessment of Japanese comic (manga) "Garasu No Kamen" into Indonesian language translation "Topeng Kaca” (the Glass Mask). International Journal of Linguistics, Literature and Culture, 4(4), 53-68. https://doi.org/10.21744/ijllc.v4n4.263

Okyayuz, A. Ş. (2017). Examining the translation and scanlation of the manga Naruto into Turkish from a translator's perspective. International Journal of English Language \& Translation Studies, 5(3), 161-173. http://hdl.handle.net/11693/49077

Perigee. (n.d.) In English Oxford living dictionaries. Retrieved April 3, 2020, from https://en.oxforddictionaries.com/definition/per igee

Paloposki, O. (2010). The translator's footprints. In T. Kinnunen, \& K. Koskinen (Eds.), Translators' agency (pp. 86-107). Tampere University Press.

Pym, A. (2004). The moving text: Localization, translation and distribution. John Benjamins.

Sanchez Ortiz, M. T. (2015). The use of footnotes in literary translation. FORUM: International Journal of Interpretation and Translation, 13(1), 111-129. https://doi.org/10.1075/forum.13.1.06san

Takeyama, Y., \& Armour, W. S. (2015). Translating Japanese typefaces in 'manga': Bleach. New Readings, 15, 21-45. https://doi.org/10.18573/newreadings. 102

Tian, C. (2014). The limits of notes in literary translation. Journal of Education, Arts and Humanities, 2(2), 1-7.

Toledano Buendía, C. (2013). Listening to the voice of the translator: A description of translator's notes as paratextual elements. Translation \& Interpreting, 5(2), 149-162. https://doi.org/10.12807/ti.105202.2013.a09

Weblio 英和辞典 - 和英辞典 [English<> Japanese Dictionary]. Retrieved April 3, 2020, from https://ejje.weblio.jp

\section{Corpora:}

Azuma, K. (2003).よつばと! 1. ASCII Media Works.

Azuma, K. (2004). よつばと! 2. ASCII Media Works.

Azuma, K. (2004).よつばと! 3. ASCII Media Works. 
Azuma, K. (2017). Yotsuba\&! 1. (Atiqyahya, Trans.). Kadokawa Gempak Starz Sdn. Bhd.

Azuma, K. (2018). Yotsuba\&! 1. (Atiqyahya \& Rinne, Trans.). Kadokawa Gempak Starz Sdn. Bhd.

Azuma, K. (2018). Yotsuba\&! 2. (Atiqyahya \& Rinne, Trans.). Kadokawa Gempak Starz Sdn. Bhd.

Azuma, K. (2018). Yotsuba\&! 2. (Atiqyahya, Trans.). Kadokawa Gempak Starz Sdn. Bhd.

Azuma, K. (2018). Yotsuba\&! 3. (Salmy Mustapa \& Rinne, Trans.). Kadokawa Gempak Starz Sdn. Bhd.

Azuma, K. (2018). Yotsuba\&! 3. (Salmy Mustapa, Trans.). Kadokawa Gempak Starz Sdn. Bhd.

Shinkai, M. \& Kotone, R. (2016). NAMAMU...01. (uepinmon, Trans.). Kadokawa Gempak Starz Sdn. Bhd.

Shinkai, M. \& Kotone, R. (2016). 君の名は01. Kadokawa Corporation.
Shinkai, M. \& Kotone, R. (2016). 君の名は02. Kadokawa Corporation.

Shinkai, M. \& Kotone, R. (2017). NAMAMU...02. (uepinmon, Trans.). Kadokawa Gempak Starz Sdn. Bhd.

Shinkai, M. \& Kotone, R. (2017). NAMAMU...03. (Atiqyahya, Trans.). Kadokawa Gempak Starz Sdn. Bhd.

Shinkai, M. \& Kotone, R. (2017). Your name. 01. (Anisa \& Rinne, Trans.). Kadokawa Gempak Starz Sdn. Bhd.

Shinkai, M. \& Kotone, R. (2017). Your name. 02. (uepinmon \& Rinne, Trans.). Kadokawa Gempak Starz Sdn. Bhd.

Shinkai, M. \& Kotone, R. (2017). Your name. 03. (Atiqyahya \& Rinne, Trans.). Kadokawa Gempak Starz Sdn. Bhd.

Shinkai, M. \& Kotone, R. (2017). 君の名は03. Kadokawa Corporation 